\title{
Late Holocene human activities and their impacts on the soils and sediments at La Playa, Sonora, Mexico
}

Tamara Cruz-y-Cruz, Guadalupe Sánchez, John Carpenter, Sergey Sedov, Hermenegildo Barceinas-Cruz, Elizabeth Solleiro-Rebolledo

Tamara Gruz-y-Gruz

tamczyc@yahoo.com.mx

Programa de Becas Posdoctorales en la UNAM, Becaria del Instituto de Investigaciones Antropológicas, asesorada por el Dr. Terrazas.

\section{Guadalupe Sánchez}

John Garpenter

Centro INAH Sonora, Jesús García S/N, La

Matanza, 83080 Hermosillo, Sonora, Mexico.

\section{Sergey Sedov}

Elizabeth Solleiro-Rebolledo

Instituto de Geología, UNAM, Ciudad Universitaria, 04510 CDMX, Mexico.

\section{Hermenegildo Barceinas-Gruz}

Posgrado en Ciencias de la Tierra, Universidad Nacional Autónoma de México, Ciudad Universitaria, 04510 CDMX, Mexico.

BOL. SOC. GEOL. MEX. 2019

VOL. 71 NO. 2

P. $519-541$

http://dx.doi.org/10.18268/BSGM2019v7 1n2a17

\section{ABSTRACT}

The activities carried out by preindustrial agricultural societies are not usually considered as important factors of soil degradation. Nonetheless, repetitive human daily activities for hundreds of years can substantially transform the natural properties of the soils. At the site of La Playa, Mexico, the activities of early farmers modified the landscape and had an important role in the physical transformations of the natural soil features. This paper depicts the characteristics of La Playa paleosols, which were the living surface of the Early Agriculture Period community $(4000-1800 \mathrm{cal} \mathrm{BP})$ and we discuss the influence of daily subsistence activities on the soil. The soil features (structuring, differentiation of horizons, texture-in field and laboratory, color, porosity, stoniness, magnetic properties, organic carbon content, carbonation, presence of cutans, nodules and/or concretions, among other pedological features) of three profiles with pedosediments (paleosols interbedded with sediments) formed during late Holocene are discussed. Our study suggests that La Playa Fluvisols are poorly developed and were formed with alluvial deposits (largely composed of reworked soils). The pedogenic properties indicate that overlapping developed during short time periods of stability, under arid conditions of the last 4000 years. The uniformity of the features in all the studied profiles indicate similar pedogenetic conditions across the site. The micromorphological and magnetic properties clearly show that the soil was deeply disturbed by human activities, mainly by roasting features to process food, crematories and grave digging to bury the dead, and removing soil for several agricultural activities.

Keywords: Soil degradation, human activities, magnetic properties, paleosols, Sonora.

\section{RESUMEN}

Las actividades realizadas por las sociedades agrícolas prehispánicas poco complejas, no son usualmente consideradas como factores importantes de degradación del suelo. Sin embargo, la repetición de actividades cotidianas durante cientos de años puede afectar sustancialmente sus características. En el sitio de La Playa, las modificaciones del paisaje producidas por las actividades cotidianas, tales como la construcción de hornos de tierra para cocer alimentos, campos de maíz con un complejo sistema de canales de riego, y la práctica de rituales mortuorios (crematorios, cremaciones e inhumaciones), juegan un papel importante en las transformaciones de los rasgos naturales del suelo. En este artículo se muestran las características de los paleosuelos de La Plava, que constituyeron la superficie de ocupación durante el Periodo de Agricultura Temprana (4500-1800 cal AP), y la influencia que las actividades de subsistencia diaria tuvieron en su configuración. Para ello, se muestran los resultados obtenidos en campo y en laboratorio de tres perfiles de secuencias pedosedimentarias formadas durante el Holoceno tardío en La Playa, Sonora (NW de México). Las características evaluadas son: estructuración, diferenciación de horizontes, textura (a tacto y por separación de fracciones), color, porosidad, pedregosidad, propiedades magnéticas, contenido de carbono orgánico, carbonatación, presencia de cutanes, nódulos y/o concreciones, entre otros rasgos pedológicos. Estudios previos muestran que los Fluvisoles de La Playa están pobremente desarrollados y se formaron a partir de depósitos aluviales (compuestos en gran medida por suelos redepositados). Las propiedades fisicas y quimicas indican periodos cortos de pedogénesis superpuestos, desarrollados bajo un clima árido durante los últimos 4000 años. Las características de todos los perfiles son muy similares, indicando las mismas condiciones pedogenéticas; mientras que las propiedades micromorfológicas y magnéticas muestran claramente que el suelo está profundamente perturbado por las actividades humanas, principalmente quema en los hornos y cremaciones.

Palabras clave: Degradación de suelo, impacto antrópico, propiedades magnéticas, paleosuelos, Sonora. 


\section{Introduction}

The anthropogenic impact on the earth surface by industrial societies is a common research topic. However, pre-industrial societies, including early agricultural societies, could have also modified their natural settings, though on a much smaller scale, from everyday activities including food production, and social and ritual practices (McAuliffe et al., 2001; McClung et al., 2003). Here we present evidence that early farmers (4000-1800 years ago) of the Sonoran Desert transformed and altered the properties of the soils contained in the Boquillas alluvial plain by preforming daily activities related to agriculture and other food production. Modern humans spent $99 \%$ of their history as hunter-gatherers (Price and Brown, 1988), a nomadic life in which people left very few archaeological remains, and left the ground surface (soils and sediments) very little modified. The practice of agriculture transformed the life of the people (Braidwood, 1960).

Social mobility was reduced greatly, and the new sedentary way of life modified the ground cover, including soils and sediment, by removing the plant coverage, transforming the ground during the construction of the fields, and making canals to water the crops. The impact that early agricultural societies had on the soils is not well known, but the repetition of the same activity for thousands of years could result in extensive transformations of the natural features of soils and change the landscape (McAuliffe et al., 2001; McClung et al., 2003; Sánchez et al., 2013). The anthropic changes in the soil properties persist and can be observed in the soil profiles today (McClung et al., 2003; Targulian and Goryachkin, 2004; Sánchez et al., 2013).

People arrived in northwest Mexico and the southwest U.S. about 13000 years ago during the late Pleistocene when grassland with oaks and juniper formed a savanna on the coastal plain, with seasonal climate very appealing for the Pleistocene megafauna and Clovis hunters (Van Devender, 1990). The Holocene witnessed the birth of the
Sonoran Desert. The climate became much more seasonal and warmer, resulting in a greater variety of plant species. Oaks and junipers were replaced by leguminous tree species such as mesquite, acacia, and paloverde (McAuliffe and Van Devender, 1998). Annuals like amaranth, chenopodium, and a wide variety of cactus permitted a sustainable culture based upon the consumption of plants and hunted animals (Carpenter et al., 2015). This new landscape harbored bands of hunter-gatherers that specialized in the manipulation and exploitation of the desert plant resources, utilizing tools to crush, scrape, grind, and cut. Hearths and roasting pits also become more frequent components. This adaptation apparently persisted with few changes over several millennia, from the Early Holocene (10000 years ago) to around 4500 years ago when the cultigen corn arrived to the region from Mesoamerica and early agricultural societies began to cultivate the alluvial fans of the Sonora Desert (Carpenter et al., 2003, 2009, 2015).

During the Early Agriculture Period (EAP) (4500 1800 cal BP) the desert communities began to cultivate corn and irrigate their field with canals (Huckell, 1995; Mabry et al., 2002; Mabry, 2008; Diehl, 2009). La Playa archaeological site in northern Mexico contains evidence of a human occupation of long duration beginning in the late Pleistocene; the maximum occupation of the site is documented between 4500 and 1800 years ago, during the EAP (Carpenter et al., 2005, 2009). Currently, the site is under the seasonal influence of a gully and sheet erosion (Copeland et al., 2012), with an absent or a poorly developed soil cover. At the site, two pedocomplexes have been observed: the San Rafael Paleosol (SRP), with a sequence of buried reddish horizons dated between 14910-4440 cal BP, and the Boquillas Paleosol (BOP), which consists of several Ah horizons discontinued by alluvial sediments. 3Ah horizon of BOP is dated from 4090-3880 cal BP (Cruz$\mathrm{y}$-Cruz et al., 2014). The EAP occupation of the site is displayed in the BOP; this soil formed on alluvial sediments and shows an incipient pedogenic processes - weathering, humification, ag- 
gregation, and carbonation. The profiles analyzed show evidence of intensive use and modification of soils and sediments by the activities of ancient people, including agricultural activities (e.g., agricultural field making, irrigation canals, beams for water control), funerary activities (grave digging, cremations), and roasting pits for food processing (Carpenter et al., 2005, 2009, 2015).

In this paper, we want to establish the predominant paleoenvironment during the Period of Early Agriculture in La Playa, as well as to identify the modifications to the soils produced by human activities, contrasting the information obtained from the soil studied with the archaeological data.

\section{Study area}

The study area (Figure 1) is located in northwest Mexico, in northern Sonora, in the Sonoran Desert biome with a predominant climate $\mathrm{BSOh}$ '(h) x' (dry semi-warm) (Vidal, 2005). The mean annual temperature ranges from $18-22{ }^{\circ} \mathrm{C}$. The mean annual precipitation is between 200 and 400 $\mathrm{mm}$, with a bimodal rainfall with summer chubascos (downpour) and winter equipatas (lightweight and low rainfall) (Vidal, 2005). The main vegetation is desert scrub type (Pérez, 1985).

The archaeological site of La Playa (SON F:10:3) (Figure 2) is located $10 \mathrm{~km}$ north of the town of Trincheras, in the municipality of the same name, at 500 masl, occupying an area of about $10 \mathrm{~km}^{2}$, spread over an alluvial fan formed in the Sierra de Boquillas foothills (Carpenter et al., 2003). The hills near the site and associated with the alluvial fan are composed of folded sedimentary rocks: Jurassic siltstone-sandstone-conglomerate in the upper parts, and Tertiary conglomerates in the lower parts. The conglomerate is composed mainly of quartz, flint, limestone, and igneous rocks, and is easily eroded in laminar form. Sandstone is the dominant rock in the hills of the Sierra de

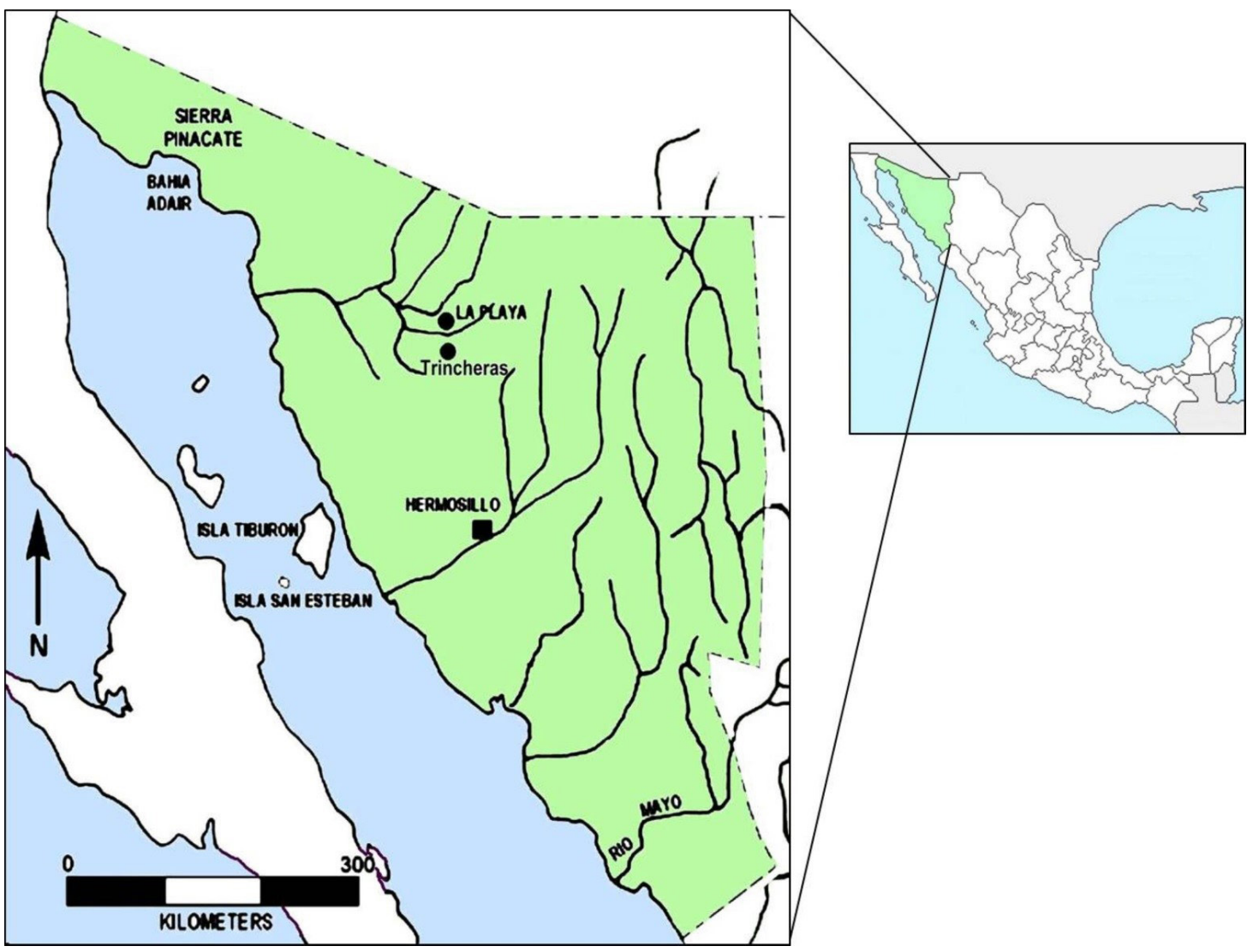






Figure 2 La Playa Archaeological Site. Red line shows the official delimitation of the site and red points show the location of the Hornos $1(\mathrm{H} 1)$, Hornos $2(\mathrm{H} 2)$ and Canal $2(\mathrm{C} 2)$ profiles. Cultural areas are indicated by legends. Aerial image modified from Google Earth, based on Villalpando et al. (2007) and Carpenter et al. (2015).

Boquillas, interspersed between the conglomerates and the shales. It consists of quartz and flint fragments, as well as significant hematite (McLaurin $e t$ al., 2007). The general slope of the terrain is NE to SW.

\subsection{LA PLAYA PALEOSOLS}

At the La Playa site, we have identified two pedogenic tendencies (Cruz-y-Cruz et al., 2014):

The San Rafael Paleosol (SRP) is represented by a red soil that developed during the late Pleistocene, representing a Chromic Cambisol soil. SRP is visible in many exposures in the western and central portions of the site. The profile type for $\mathrm{SRP}$ is Hornos 1, and it is located at $30^{\circ} 29^{\prime} 58^{\prime \prime} \mathrm{N}$ and $111^{\circ} 31^{\prime} 44.6^{\prime \prime} \mathrm{W}$, at an elevation of 510 masl. The profile shows a sequence of buried reddish horizons: C-2A-2Bw-2BCk-3Bgk-3BCg-3C (Fig- ure 3). The development of this red soil has been dated between 14910-14230 cal BP in 3Bgk carbonates, and probably between $4440-4259 \mathrm{cal}$ BP in charcoal from 2A horizon (Cruz-y-Cruz et al., 2014). These pedological units have been identified in several sites in NW Sonora (Cruz-y-Cruz et al., 2015; Sanchez, 2016). In several exposures, the red paleosol (SRP) is buried by a thin sediment where late Holocene soils subsequently developed. The other pedogenetic tendency is represented by a set of weak paleosols developed during the middle and late Holocene under much more mesic environment than the SRP (Figure 3), and classified as Fluvisol according to the WRB (2006). These paleosols constitute a pedological unit we call Boquillas Paleosol (BOP). To evaluate the anthropic impact on the paleosols, three profiles containing the BOP were analyzed and studied. Soil profiles were described in the field, following the rules of 


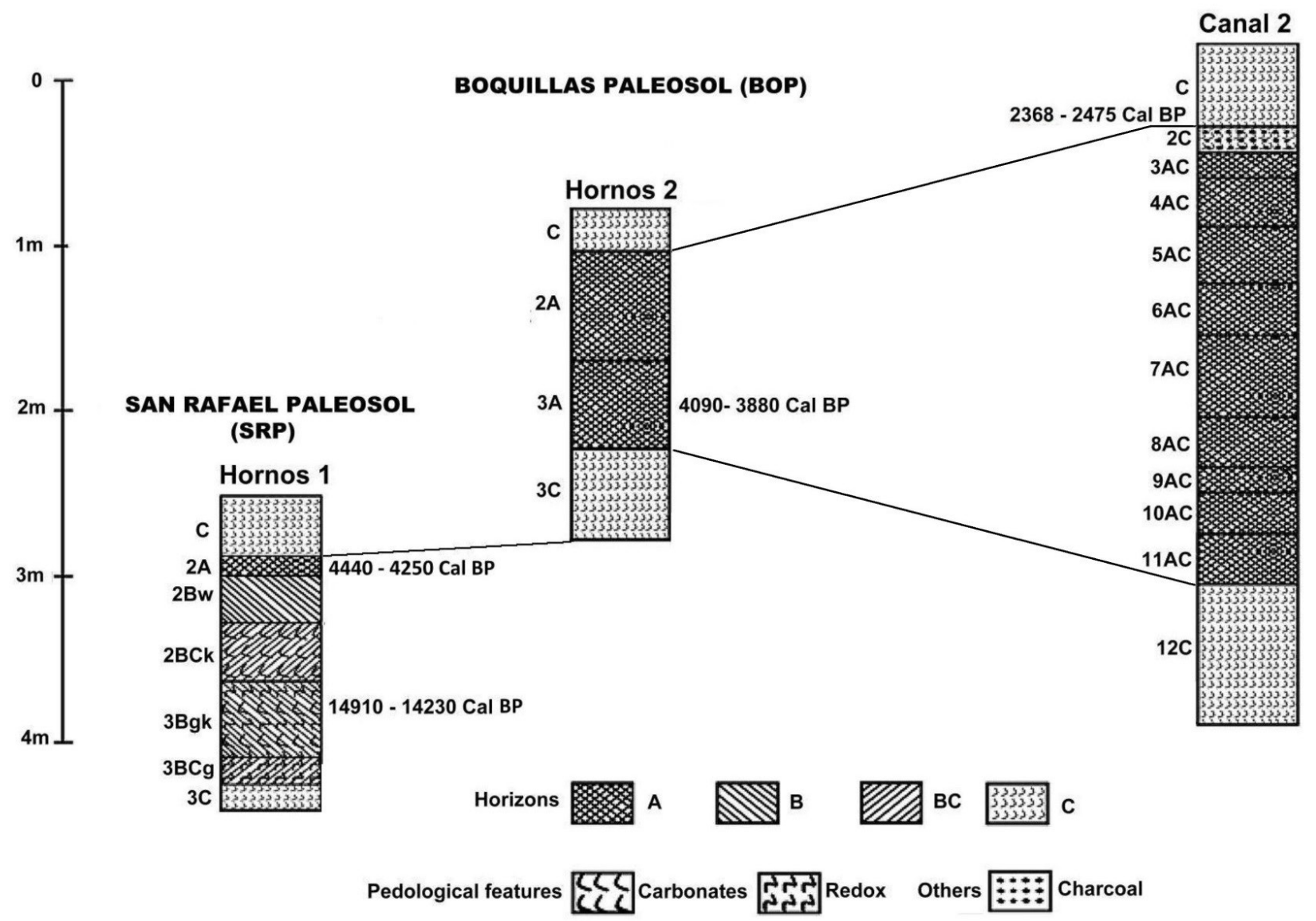

Figure 3 Correlation of the La Playa profiles. Hornos 1 profile is part of the San Rafael Paleosol (SRP), developed during the PleistoceneHolocene transition. The SRP was buried by sediments in the middle Holocene from which the BOP was formed. BOP is represented by Hornos 2 and Canal 2 profiles.

the WRB (2006) for their identification, description, and classification of horizons. Their morphological attributes were described (e.g, depth, boundaries, color, organic matter, texture feature, structure, compaction, porosity), and the pedogenic features were identified (e.g., cutans, accumulations, concretions).

\subsection{ANTHROPOGENIC ACTIVITIES IN LA PLAYA}

La Playa site reflects an archaeological landscape encompassing 10 square kilometers located in northern Sonora, Mexico, and reveals archaeological evidence of more or less continuous human presence since the Paleoindian period (ca. 13000 years ago). Its most intensive use was during the EAP (4500-1800 cal BP); after this period, the occupation of the Boquillas Valley diminished, but the site was continuously occupied by the Trincheras tradition, Pima groups, and French goat herders, and even a hotel and restaurant was in operation there during the 1950s (Carpenter et al., 2003, 2005, 2008, 2015).

During the EAP humans began to manipulate their environment in significant ways related to agricultural production. La Playa contains an extensive paleo-climatological record and the remains of massive prehistoric irrigation systems (Carpenter et al., 2015). Ongoing geoarchaeological investigations at the site contribute greatly to our understanding of this intensively manipulated landscape and model the history of climate change that brackets the EAP and the agricultural system that shaped the landscape (Carpenter et al., 
2015). Measurable climate change marks the beginning and end of the EAP in the Sonoran Desert, a period characterized by the development and implementation of a sustainable model of agriculture that led to significant population growth and cultural development in the Trincheras, Sonora region (Carpenter et al., 2015).

It was during the EAP that human occupation in La Playa reached its maximum size and population; at its zenith, the site grew to encompass approximately 10 square kilometers during the latter portion of the Cienega phase (800 BCE to 150 CE) occupation. At La Playa, the earliest radiocarbon date for this period is $3720 \pm 320$ (4891-3322 cal BP) (AA53243) and is associated with the burial of an adult female 25-35 years old (Feature 323) (Carpenter et al., 2015).
During the EAP, the La Playa population modified the alluvial fan of the Boquillas River by building corn fields, irrigation canals, and an artificial reservoir, and digging roasting pits, graves, crematories, and pit-houses. In the area between paleosols and burials (Figure 2) 600 roasting pits were recorded. Extrapolating to the entire site, we estimate there could have been between 3000 and 4000 pits (Figures $4 \mathrm{a}$ and $4 \mathrm{~b})$. The predominant features associated with the EAP are several hundred human inhumation and cremation burials, numerous dog burials, shell ornament production and lithic reduction activity areas, caches of "ground stones" and tabular "lap stone" slabs, and a schist quarry. Eighty-three roasting pits have been excavated ranging from 0.45 to $4.02 \mathrm{~m}$ in diameter, and range from 0.50 to $1.18 \mathrm{~m}$ in depth, and most
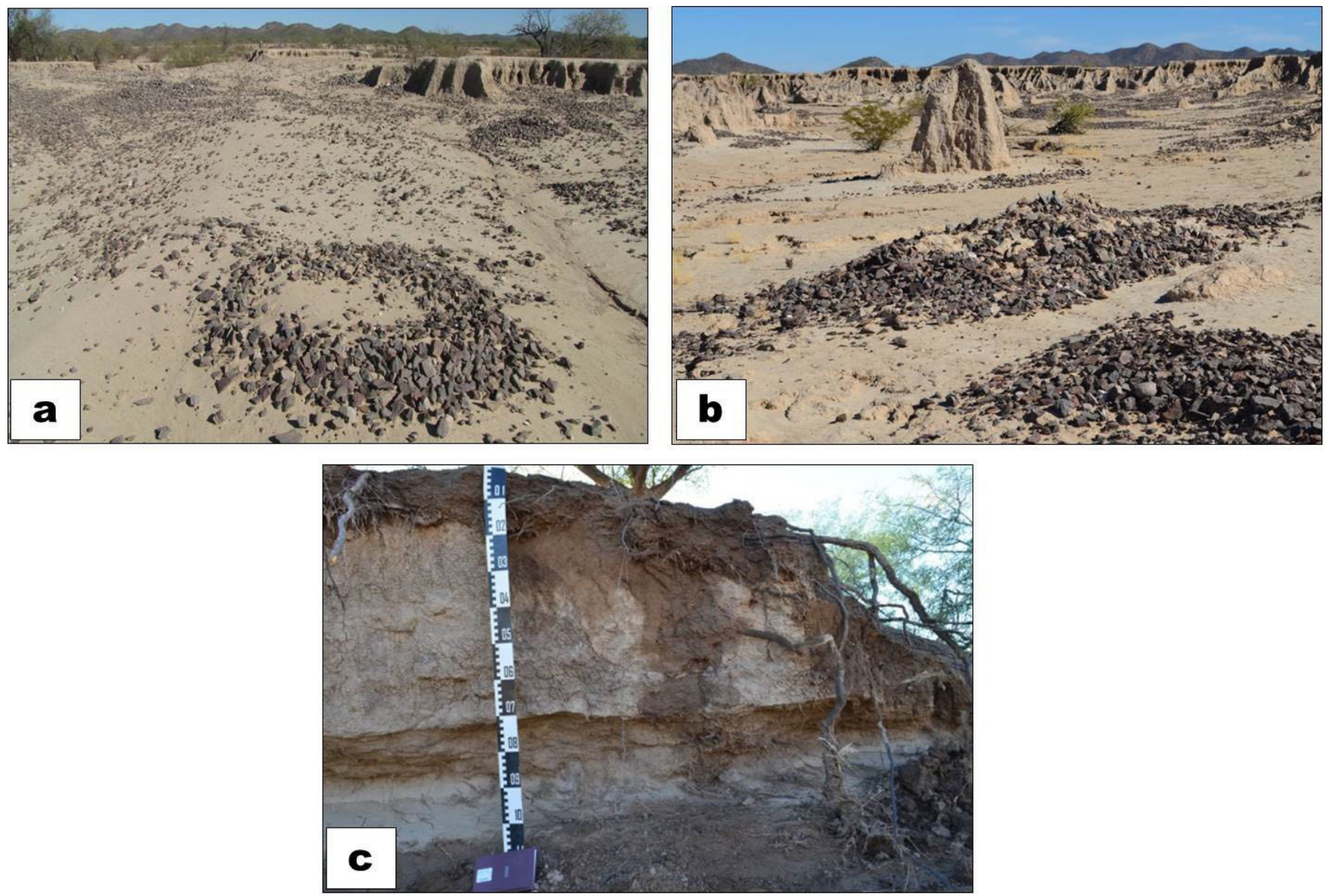

Figure 4 Cultural features: a) and b) remains of stone ovens modified by erosion, c) cross section of irrigation channel, for agriculture. Photos courtesy of Proyecto Arqueológico La Playa, INAH. 
reflect a globular profile (Martinez-Tagueña and Sanchez, 2005). However, some roasting features reach monumental mound proportions, exceeding $10 \mathrm{~m}$ in diameter, and rising to $2 \mathrm{~m}$ above the surrounding surface; at least some would appear to have been constructed as mounds and do not likely reflect the result of surrounding deflation of previously subterranean features (Carpenter et al., 2015). Their immense proportions are likely indicative of community-wide ritual feasting activity. One oven (Feature 146) contained elements representing at least 10 red tailed hawks (Buteo jamaicensis) (Martínez-Lira et al., 2011); the lack of charring or cut marks, and the number of bones representing wings and phylanges are suggestive of bird bundles utilized for medicinal rituals (Martínez-Lira et al., 2011). Similarly, another unusual roasting feature was found to contain the remains of 24 crows (Corvus corax), sans cranial and rib elements, and may also likely represent a ritual bird bundle (Martínez-Lira et al., 2011). There is no quantification of the number of existing ovens and burials, but they are distributed throughout the alluvial fan, in an area of approximately 4.5 $\mathrm{km}$ east-west and $2 \mathrm{~km}$ north-south (although ovens have been located northeast of the Sierra de Boquillas). Additionally, the highly fractured condition of the fire-cracked rock within the roasting features suggests that water may have been employed in the roasting process, and the linear arrangement of the pits may reflect placement along canals (Carpenter et al., 2015).

In aerial photographs, it is possible to see the evidence of agricultural fields covering 35 hectares. Canals have also been identified in the gully erosion of some profiles (Figure 4c). Currently, there are no investigations of the agricultural field systems and canals at the La Playa site, and we do not know the extent and nature of the field agriculture at the site. However, similar features to those observed at La Playa, from the same period, have been investigated in Las Capas in the Tucson Basin (Vint, 2018). At the Las Capas site, five acres of land were scraped with a backhoe with a specially shaped blade; over 5530 cultural features were identified, including 55 pit houses, 22 human burials, 656 bell-shaped pits, 527 roasting pits, and over 3500 small pits (Whitney et al., 2014). Canals and fields were exposed in considerable detail (Vint, 2018). The habitation areas, with small clusters of houses, were located adjacent to the field, as well as roasting pits and burials (Vint, 2018). The similarity between both sites leads us to suggest a similar arrangement of features at La Playa site.

Along the Río Boquillas alluvial plain, people began to inhabit permanent settlements and eventually completely transformed the alluvial plain with an agricultural system composed of fields, canals, and artificial reservoirs. Roasting plants and animals to preserve food for later was an important activity and roasting features represent an important element in the landscape. The La Playa site grew to encompass 10 square kilometers (Carpenter et al., 2015) and reveals a particularly close affinity with Las Capas, and the Tucson Basin in general, especially regarding material culture, beginning during the San Pedro phase (4000-2800 cal BP), suggestive of a shared social network, trade contacts, or perhaps, migration (Watson, 2011; Vint, personal communication, 2014).

\section{Materials and methods}

For this work, we reviewed previous analytical results of the profiles (grain size composition, dithionite-extractable iron, organic carbon, carbonate content, and radiocarbon dating), adding detailed analyzes of their magnetic and micromorphological properties.

Grain size composition was analyzed following the USDA procedure (USDA, 2004). The particle size was quantified by separating fractions, after the elimination of main soil aggregation agents (humus, carbonates, and iron oxides). The sands were separated by sieving, while silts and clays by sedimentation in a water column. Particle sizes 
influence several soil properties, such as structure, density, compaction and pore size distribution, moisture retention, air capacity, and specific surface area.

Dithionite-extractable iron $\left(\mathrm{Fe}_{\mathrm{d}}\right)$. For this analysis, free iron oxides were extracted and quantified. We used sodium dithionite and sodium citrate for the reduction process, following Mehra and Jackson (1960). The filtrate fraction was analyzed by atomic absorption spectrometry using a Perkin Elmer Model 3110 at the Soil Science Department in the Institute of Geology, UNAM.

Organic carbon content $\left(\mathrm{C}_{\text {org }}\right)$ was obtained using an elemental analyzer CHNS/O Perkin Elmer 2400 series II at the Soil Science Department, Institute of Geology, UNAM following Schlichting and Blume (1966).

Carbonate content $(\%)$ was determined based on procedures established by the United States Department of Agriculture (USDA, 2004). Dry samples were weighed and a $5 \mathrm{M} \mathrm{HCl}$ solution was added until all carbonates were dissolved. Subsequently, the sample was washed and dried in an oven, and then re-weighted. The percentage of carbonates was determined by weight difference between the initial weight sample and the weight after the treatment with $\mathrm{HCl}$.

Radiocarbon dating. The humic acids of the paleosols were dated by Accelerator Mass Spectrometry (AMS) in Beta Analytics laboratories.

Magnetic properties. To measure the magnetic properties, samples were collected every $10 \mathrm{~cm}$ along the profiles. The dry samples were gently crushed and tightly packed into cubic diamagnetic boxes with volumes of $8 \mathrm{~cm}^{3}$. The mass of every sample was measured, and the normalized mass was calculated. Magnetic susceptibility in low $(0.47$ $\mathrm{kHz})$ and high $(4.7 \mathrm{kHz})$ frequencies $\left(\chi_{\mathrm{If}}\right.$ and $\chi_{\mathrm{hf}}$, respectively) was measured with a Bartington MS2B susceptibility meter with dual sensor. Magnetic susceptibility increments in a sample are good indicators of magnetic minerals concentration (such as magnetite and hematite). Also, the dependent magnetic susceptibility frequency $\left(\chi_{\mathrm{fd}}\right)$ was calculated; this parameter indicates the presence of ul- tra-fine grained superparamagnetic (SP) particles $(\mathrm{d}<0.01 \mu \mathrm{m})$, which are produced during pedogenesis (Worm, 1998). Anhysteretic remnant magnetization (ARM) was measured with a Molspin $\mathrm{AF}$ demagnetizer using an AF field of $100 \mathrm{mT}$ combined with a bias field of $50 \mu \mathrm{T}$. ARM is useful for identifying the presence of low coercive magnetic minerals such as magnetite and maghemite, which are considered the final product of some pedological processes (Dearing et al., 1996). Isothermal remnant magnetization(IRM) of $100 \mathrm{mT}$ was applied with a ASC M10 pulse magnetizer, and the ratio ARM/IRM was calculated, which is a good indicator of the presence of fine grain size single domain $(\mathrm{SD})$ magnetic particles $(0.1 \mu \mathrm{m}>\mathrm{d}$ $>0.01 \mu \mathrm{m})$ (King et al., 1982). Once the SIRM was reached at $1000 \mathrm{mT}$, backward fields were applied in intervals of $10 \mathrm{mT}$, until a magnetization in the opposite direction was observed in the sample, and the remnant coercive field (Hcr) was found. A decrease of Hcr indicates an increase in concentration of ferromagnetic minerals. All magnetic remanences were measured in a Molspin fluxgate magnetometer.

Soil micromorphology. For this analysis, undisturbed samples (preserving their structure and orientation) were collected. Thin sections were prepared and observed using a petrographic microscope Olympus America BX51 brand. Thin sections were analyzed with polarized light and crossed polarizers to identify the characteristics of the groundmass and pedogenetic processes, according to Stoops et al. (2010).

In addition, the geomorphological units of the alluvial fans were delimited based on Bull (1991). The degree of erosion of the surfaces of the alluvial fans were evaluated based on their morphological characteristics observed in satellite images: crest and topography, the type and degree of dissection, the presence of desert pavement, and the presence and type of vegetation. The geomorphological surfaces of the alluvial fans $(\mathrm{Q})$ were numbered from 1 to 5 , with number 1 being the oldest and 5 the youngest. Likewise, typological subdivisions were carried out, indicated by letters in alphabetical order, according to Table 1. 
Table 1. Correlation between Geomorphological Units, depositional environments, estimated age, soil types and climate proposed, according to their morphological characteristics; according to what was established by Bull (1991) for the sequences of alluvial fans in the region of Río Colorado, USA.

\begin{tabular}{|c|c|c|c|c|}
\hline Geomorphic Unit & $\begin{array}{l}\text { Depositional } \\
\text { environment }\end{array}$ & $A g e(K a B P)$ & Sequence of soil horizons & Proposed climate: \\
\hline \multirow{2}{*}{ Q5 } & \multirow{2}{*}{ Recent } & Late Holocene & \multirow{2}{*}{ None / A incipient (Fluvisols) } & \multirow{2}{*}{ Dry } \\
\hline & & 0 & & \\
\hline \multirow{2}{*}{ Q4b } & \multirow{2}{*}{ Late interglacial } & Late Holocene & \multirow{2}{*}{ None / A incipient (Fluvisols) } & \multirow{2}{*}{ Dry } \\
\hline & & $0.1-2$ & & \\
\hline \multirow{2}{*}{ Q4a } & \multirow{2}{*}{ Late interglacial } & Late Holocene & \multirow{2}{*}{ None / A incipient (Fluvisols) } & \multirow{2}{*}{ Dry } \\
\hline & & $2-4.5$ & & \\
\hline \multirow{2}{*}{ Q3c } & \multirow{2}{*}{ Interglacial } & Middle Holocene & \multirow{2}{*}{ A (Fluvisols) } & \multirow{2}{*}{ Dry } \\
\hline & & $4.5-6$ & & \\
\hline \multirow{2}{*}{ Q3b } & \multirow{2}{*}{ Interglacial } & Middle Holocene & \multirow{2}{*}{ A (Flvisols) } & \multirow{2}{*}{ Dry } \\
\hline & & $6-7.5$ & & \\
\hline \multirow{2}{*}{ Q3a } & \multirow{2}{*}{ Glacial to Interglacial } & $\begin{array}{l}\text { Early Holocene / } \\
\text { Late Pleistocene }\end{array}$ & $\mathrm{A} / \mathrm{Bw}$ or none & \multirow{2}{*}{ Dry to semi-dry } \\
\hline & & $7.5-15$ & $\begin{array}{c}\text { (Fluvisols, Cambisols, } \\
\text { Calcisols) }\end{array}$ & \\
\hline \multirow[b]{2}{*}{ Q2c } & Glacial & Late Pleistocene & $\mathrm{A}, \mathrm{Bt} / \mathrm{Bk}$ & \multirow[b]{2}{*}{ Semidry } \\
\hline & $\begin{array}{l}\text { Deposition pulses during } \\
\text { heating periods in the } \\
\text { middle of glacial } \\
\text { conditions }\end{array}$ & $15-70$ & (Luvisols, Calcisols) & \\
\hline \multirow{2}{*}{ Q2b } & \multirow{2}{*}{ Interglacial } & Late Pleistocene & $\mathrm{A}, \mathrm{Bt} / \mathrm{Bk}$ & \multirow{2}{*}{ Dry to semi-dry } \\
\hline & & $70-200$ & (Luvisols, Calcisols) & \\
\hline \multirow{2}{*}{ Q2a } & \multirow{2}{*}{ Interglacial } & Middle Pleistocene & $\mathrm{A}, \mathrm{Bt} / \mathrm{Bk}$ & \multirow{2}{*}{ Dry to semi-dry } \\
\hline & & $400-730$ & (Luvisols, Calcisols) & \\
\hline \multirow{2}{*}{ Q1a, Q1b y Q1c } & \multirow{2}{*}{ Glacial and Interglacial } & Early Pleistocene & & \multirow{2}{*}{ Dry to semi-dry } \\
\hline & & $>1200$ & & \\
\hline
\end{tabular}

\section{Results}

\subsection{GEOMORPHIC FEATURES AND FIELD DESGRIPTION OF BOP}

The archaeological remains are found mainly on the alluvial surface Q4a, formed during the late Holocene (see Figure 5). SRP is present in the Hornos 1 profile, in the geomorphic unit Q3a, underlying sediments that form Q4a unit, and has been expose to the surface in a recent erosion. The Hornos 2 and Canal 2 profiles are part of the Q4a unit, which has also been affected by recent erosion that allowed the cultural surface to get exposed. The Canal 2 profile is more affected by the fluvial dynamics of the Boquillas River, and the modern channel of the river runs on the Q5 unit. The Q4a unit receives sediment input from the Sierra de Boquillas, as well as from the Q1 and Q3b units. 


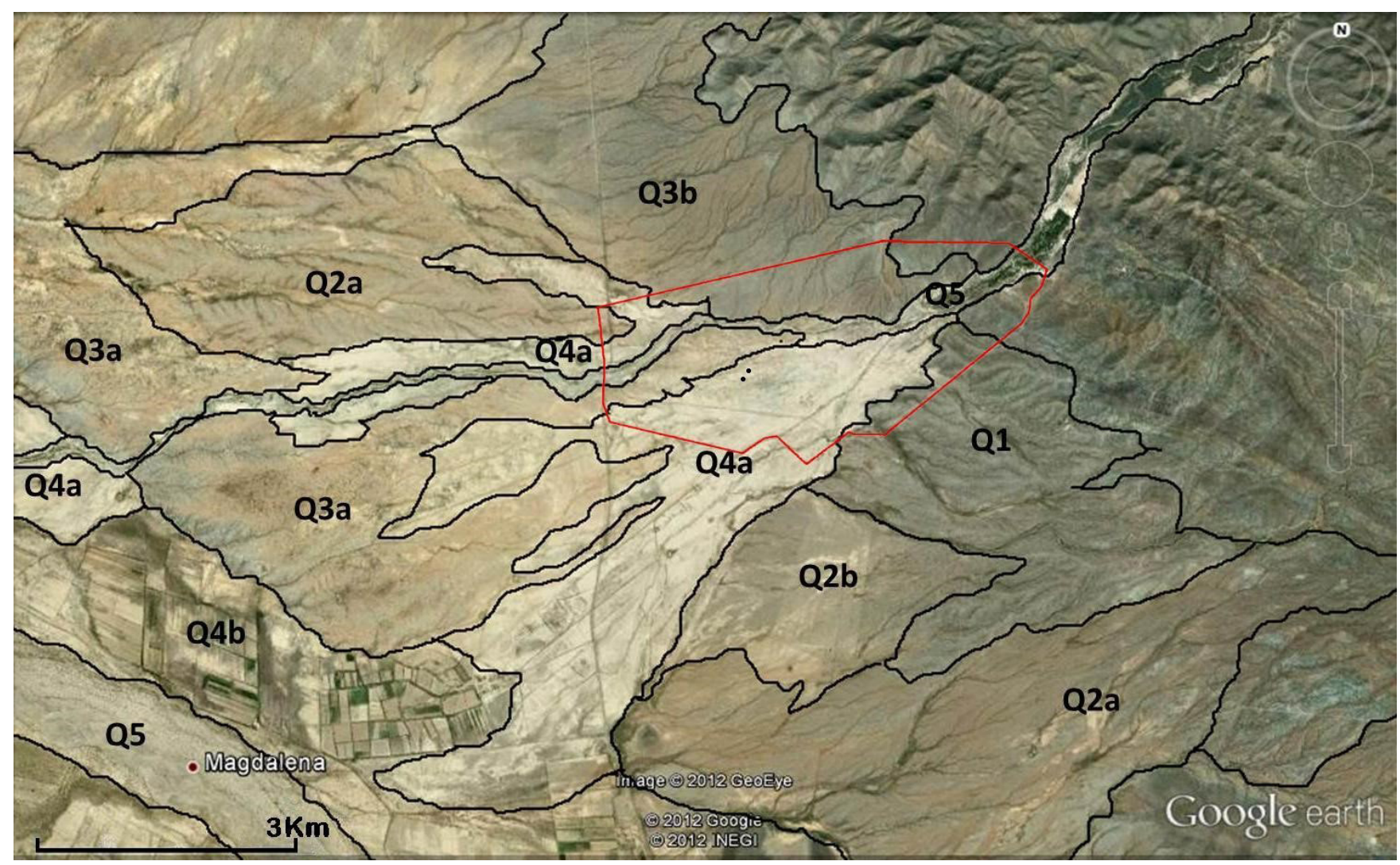

Figure 5 Geomorphic units of the alluvial fans of the study area. The units (Q) were numbered from the oldest Q1 to the most recent Q5. The polygonal line indicates the area with archaeological evidence, and includes the units Q3b, Q4a and Q5. Satellite image modified from Google Earth.

Two profiles of the Boquillas Paleosol (BOP), the Hornos 2 profile in the central part of the alluvial fan and the Canal 2 profile near the mouth, were described.

The Hornos 2 profile (Figures 2 and 6a) is a pedosediment pedestal located in the middle of the alluvial fan, in the west sector of the site, $30^{\circ} 30^{\prime} 1.9^{\prime \prime}$ $\mathrm{N}, 111^{\circ} 31^{\prime} 42.7^{\prime \prime} \mathrm{W}$, with an elevation of 514 masl. A silty-sandy sediment is noted in the upper section of the profile. One meter below this horizon paleosols are present with a C-2A-3A-3C-4C sequence (see Table 2 for descriptions). The Hornos 2 profile should correlate on the top of the Hornos 1 profile, and it is a paleosol pedestal. At the base of the pedestal a silty sediment with two incipient soils formation was recorded.

The Canal 2 profile (Figures 2 and 6b) is located near the modern channel of the Boquillas River, SW of the Sierra de Boquillas. Its geographical coordinates are: $30^{\circ} 30^{\prime} 22.8^{\prime \prime} \mathrm{N}, 111^{\circ} 30^{\prime} 29.1^{\prime \prime} \mathrm{W}$, at 524 masl. It was described in a section from the actual surface to a depth of $4.10 \mathrm{~m}$. It is a deep pedosedimentary sequence with C-2C-3AC-4AC5AC-6AC-7AC-8AC-9AC-10AC- 11 AC-12C horizons (the main field features are show in Table 2).

\subsection{ANALYTIG FEATURES OF BOP}

\subsubsection{PHYSICAL AND CHEMICAL PROPERTIES}

The analytical results are presented in Figure 7. The highest content of organic carbon was in a $2 \mathrm{~A}(0.465 \%)$ horizon from the Hornos 2 profile, followed by $2 \mathrm{C}(0.409 \%)$ horizon from the Canal 2, and the minimum values are in $\mathrm{C}$ and $3 \mathrm{C}$ $(0.165 \%)$ from Hornos 2 , followed by $\mathrm{C}(0.09 \%)$ and $12 \mathrm{AC}(0.06 \%)$ from Canal 2. At the Hornos 2 profile, the sediment closer to the actual surface 

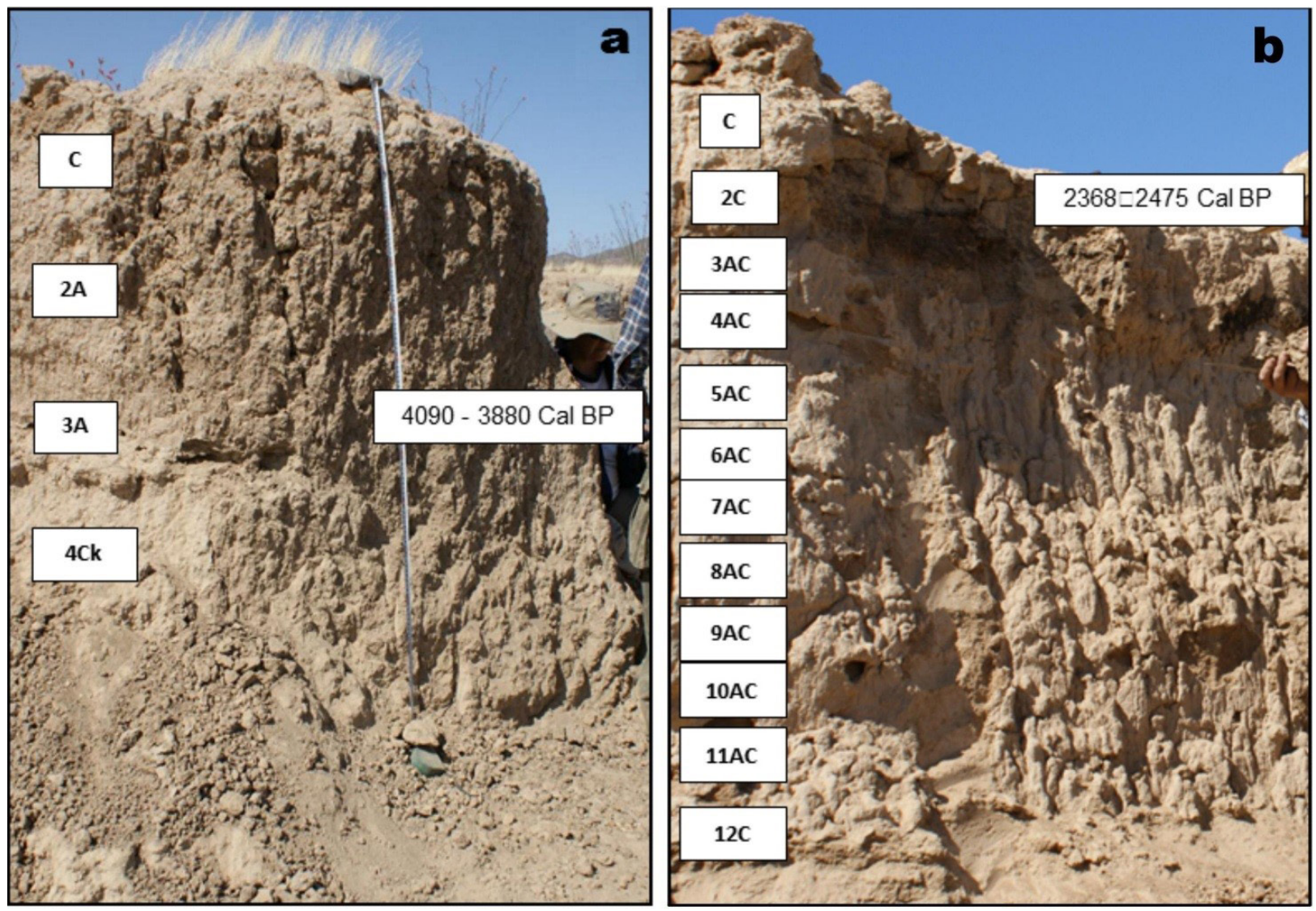

Figure 6 Boquillas Paleosol profiles studied: a) Hornos 2 profile and b) Canal 2 profile. Photos courtesy of Proyecto Arqueológico La Playa, INAH.

is sandy-silt with low clay. Significant changes were observed in the percentages of fraction size from each horizon; clay content ranges from $6.4 \%$ to $23.1 \%$, and silt content ranges between 53.3 $\%$ and $66.2 \%$. At Canal 2 profile (Figure 7), the highest percentage of sand was found at the base of the profile, in the alluvial sediments $(57.2 \%)$, and the clay fraction is also significant (between $23.7 \%$ and $36.1 \%$ ).

The maximum amount of $\mathrm{Fe}_{\mathrm{d}}(5.4 \mathrm{mg} / \mathrm{g})$ was measured at the $6 \mathrm{AC}$ horizon at the Canal 2 profile incorporated in the alluvial fan from in situ soils in the lower bajada of the Sierra de Boquillas. In the Hornos 2 profile, the minimum contents of Fed were observed in $\mathrm{C}$ horizons, incrementing in $2 \mathrm{~A}(4.13 \mathrm{mg} / \mathrm{g})$ and $3 \mathrm{~A}(4.12 \mathrm{mg} / \mathrm{g})$ horizons.

While the horizons in both profiles are carbonated, the paleosols closer to the ground surface contain more. The maximum carbonates was observed in the horizon $2 \mathrm{C}(8.8 \%)$ from the Canal 2 profile, followed by $2 \mathrm{~A}(6.9 \%)$ from Hornos 2 , while the minimum content was observed in the horizons 8AC $(3.9 \%)$ of Canal 2 and $3 \mathrm{~A}(3.6 \%)$ of Hornos 2 . The unexpected changes of the amount of carbonate between the horizons probably indicates separate periods of pedogenesis.

\subsubsection{Specific magnetic properties}

At the Hornos 2 profile (Figure 8), magnetic susceptibility $\chi$ has its maximum sum in the silty sediments found at the ground surface ( $\mathrm{C}$ horizon). The 2A horizon has lower values of $\chi$ than the $\mathrm{C}$ horizon; however, the $2 \mathrm{~A}$ horizon exhibit high values of parameters indicative of fine and ultra-fine magnetic particles $\left(\chi_{\mathrm{fd}}\right.$ and ARM/IRM) and low coercivity (ARM and Hcr). The rest of the horizons near the bottom of the profile have low values of every parameter, except for the increment 
Table 2. Field description of the pedo-sedimentary profiles, showing the main features: type of aggregation, texture to the touch, compaction, color by comparison with the Munsell color chart, presence of carbonate concretions (observable and/or by its effervescence with $\mathrm{HCl}$ ) and description of horizons limits.

\begin{tabular}{|c|c|c|c|}
\hline Profile & Horizon & Thickness (cm) & Characteristics / Observations \\
\hline \multirow{5}{*}{ Hornos 2} & $\mathrm{C}$ & $0-20$ & $\begin{array}{l}\text { Compacted sediments, with laminar structure, sandy-loam texture, dry color } 10 \text { YR } 6 / 3 \\
\text { pale brown and wet } 10 \text { YR } 4 / 2 \text { dark gray-brown, contains carbonates, clear and } \\
\text { horizontal contact. }\end{array}$ \\
\hline & $2 \mathrm{~A}$ & $20-70$ & $\begin{array}{l}\text { Structure in subangular blocky, with tendency to granular, silt-loam texture, high } \\
\text { porosity, dry color } 7.5 \text { YR } 6 / 2 \text { pink and wet gray } 7.5 \text { YR } 4 / 2 \text { brown, contains abundant } \\
\text { fine vermicular carbonates, diffuse and irregular contact. }\end{array}$ \\
\hline & $3 \mathrm{~A}$ & $70-110$ & $\begin{array}{l}\text { Well-developed structure in thick angular blocks, loam texture, high porosity, dry color } \\
7.5 \text { YR } 6 / 2 \text { pink and wet gray } 7.5 \text { YR } 4 / 2 \text { brown, with vermicular carbonates, diffuse and } \\
\text { irregular contact. }\end{array}$ \\
\hline & $3 \mathrm{C}$ & $110-160$ & $\begin{array}{l}\text { Slightly structured material, very compacted, loam texture, porous, dry color } 10 \text { YR } 6 / 3 \\
\text { pale brown and wet } 10 \text { YR } 4 / 2 \text { dark grayish brown, fine vermicular carbonates, clear and } \\
\text { irregular contact. }\end{array}$ \\
\hline & $4 \mathrm{C}$ & $160-200$ & $\begin{array}{l}\text { Compacted material, silt-loam texture, dry color } 10 \text { YR } 7 / 3 \text { very pale brown and wet } 10 \\
\text { YR } 5 / 3 \text { brown, few carbonates, overlays the SRP, clear and horizontal contact. }\end{array}$ \\
\hline \multirow{12}{*}{ Canal 2} & $\mathrm{C}$ & $0-50$ & $\begin{array}{l}\text { Laminated silty sediment, dry color } 10 \text { YR } 7 / 3 \text { very pale brown and wet } 10 \text { YR } 5 / 4 \\
\text { yellowish brown, contains carbonates, clear and horizontal contact. }\end{array}$ \\
\hline & $2 \mathrm{C}$ & $50-65$ & $\begin{array}{l}\text { Layer of burned, compacted and hardened material, dry color } 10 \text { YR } 6 / 3 \text { pale brown and } \\
\text { wet } 10 \text { YR } 3 / 3 \text { dark brown, silty texture, abundant vermicular carbonates, clear and } \\
\text { horizontal contact. }\end{array}$ \\
\hline & $3 \mathrm{AC}$ & $65-80$ & $\begin{array}{l}\text { Structure in subangular blocks, silt-loam texture, dry color } 10 \text { YR } 7 / 2 \text { light gray and wet } \\
10 \text { YR } 4 / 3 \text { brown, contains organic matter and carbonates, diffuse and irregular contact. }\end{array}$ \\
\hline & $4 \mathrm{AC}$ & $80-110$ & $\begin{array}{l}\text { Structure in subangular blocks, sandy-loam texture, dry color } 10 \text { YR } 7 / 2 \text { light gray and } \\
\text { wet } 10 \text { YR } 4 / 3 \text { brown, contains low organic matter, carbonates, diffuse and irregular } \\
\text { contact. }\end{array}$ \\
\hline & $5 \mathrm{AC}$ & $110-145$ & $\begin{array}{l}\text { Structure in subangular blocks, silt-loam texture, dry color } 10 \text { YR } 7 / 2 \text { light gray and wet } \\
10 \text { YR } 4 / 3 \text { brown, contains abundant organic matter, carbonates and charcoal, diffuse and } \\
\text { irregular contact. }\end{array}$ \\
\hline & $6 \mathrm{AC}$ & $145-175$ & $\begin{array}{l}\text { Structure in subangular blocks, silt-loam texture, dry color } 10 \text { YR } 7 / 2 \text { light gray and wet } \\
10 \text { YR } 4 / 3 \text { brown, contains organic matter, carbonates and charcoal, diffuse and irregular } \\
\text { contact. }\end{array}$ \\
\hline & $7 \mathrm{AC}$ & $175-225$ & $\begin{array}{l}\text { Structure in subangular blocks, sandy-loam texture, dry color } 10 \text { YR } 7 / 2 \text { light gray and } \\
\text { wet } 10 \text { YR } 4 / 3 \text { brown, with little organic matter, charcoal fragments, diffuse and irregular } \\
\text { contact. }\end{array}$ \\
\hline & $8 \mathrm{AC}$ & $225-255$ & $\begin{array}{l}\text { Structure in subangular blocks, silty-clay-loam texture, dry color } 10 \text { YR } 6 / 2 \text { light gray } \\
\text { brown and wet } 10 \text { YR } 4 / 3 \text { brown, contains organic matter, carbonates and charcoal } \\
\text { fragments, diffuse and irregular contact. }\end{array}$ \\
\hline & $9 \mathrm{AC}$ & $255-270$ & $\begin{array}{l}\text { Structure in subangular blocks, silt-loam texture, dry color } 10 \text { YR } 7 / 2 \text { light gray and wet } \\
10 \text { YR } 4 / 3 \text { brown, with organic matter and carbonates, diffuse and irregular contact. }\end{array}$ \\
\hline & $10 \mathrm{AC}$ & $270-295$ & $\begin{array}{l}\text { Structure in subangular blocks, silt-loam texture, dry color } 10 \text { YR } 7 / 2 \text { light gray and wet } \\
10 \text { YR } 4 / 2 \text { dark grayish brown, contains organic matter and carbonates, diffuse and } \\
\text { irregular contact. }\end{array}$ \\
\hline & $11 \mathrm{AC}$ & $295-325$ & $\begin{array}{l}\text { Structure in subangular blocks, silt-loam texture, dry color } 10 \text { YR } 7 / 2 \text { light gray and wet } \\
10 \text { YR } 4 / 3 \text { brown, with organic matter, diffuse and irregular contact. }\end{array}$ \\
\hline & $12 \mathrm{C}$ & $325-410$ & $\begin{array}{l}\text { Sediment compacted, unstructured, with sandy-loam texture, dry color } 10 \text { YR } 6 / 3 \text { pale } \\
\text { brown and wet } 10 \text { YR } 3 / 3 \text { dark brown, with carbonates. }\end{array}$ \\
\hline
\end{tabular}



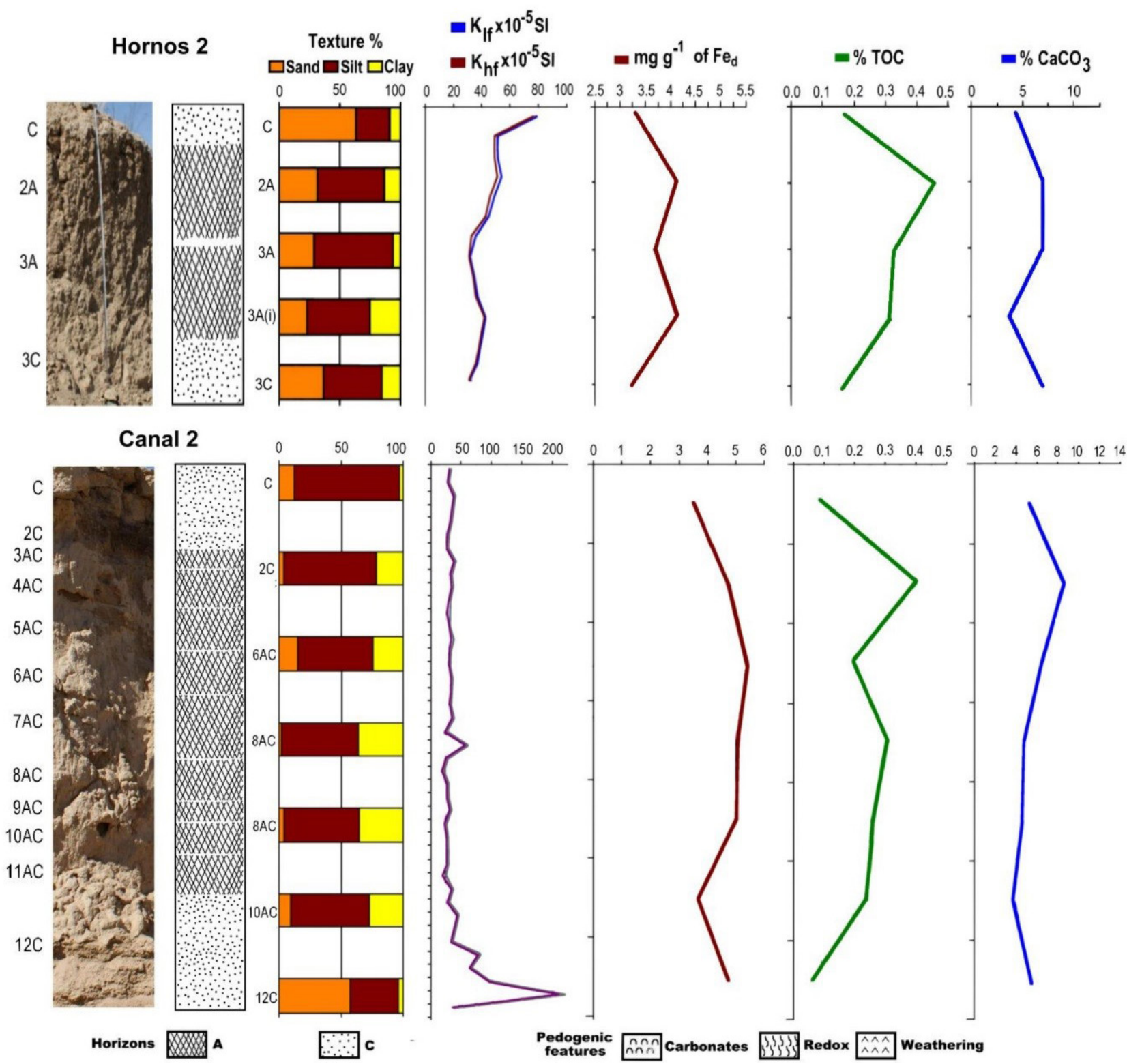

Analytic results of Boquillas Paleosols profiles.

of $\mathrm{Hcr}$ that indicates greater concentration of high coercivity magnetic minerals.

The Canal 2 profile (Figure 9) has low and homogeneous $\chi_{\text {If }}$ values, except for the $12 \mathrm{C}$ horizon in the bottom with an increase of this parameter. Variations in the $\chi_{\mathrm{fd}}$ and ARM among $\mathrm{AC}$ and $12 \mathrm{C}$ suggest that parent material in $\mathrm{AC}$ horizons contains very little ferromagnetic minerals in their native form, and the magnetic properties of $12 \mathrm{C}$ horizon are mainly inherited from coarse grained particles of the alluvial parent material that some- how was incorporate to the horizon. The high values observed in the strata with the anthropogenic influence on the Hornos 2 and Canal 2 profiles are likely to be the result of human activities. We propose that these horizons were altered by human occupation and could be classified as anthropogenic deposits (2A at Hornos 2 and 2C at Canal 2).

\subsubsection{MICROMORPHOLOGICAL FEATURES OF BOP}

The micromorphological analysis shows that in all the horizons, the groundmass is composed of 


\section{Hornos 2}

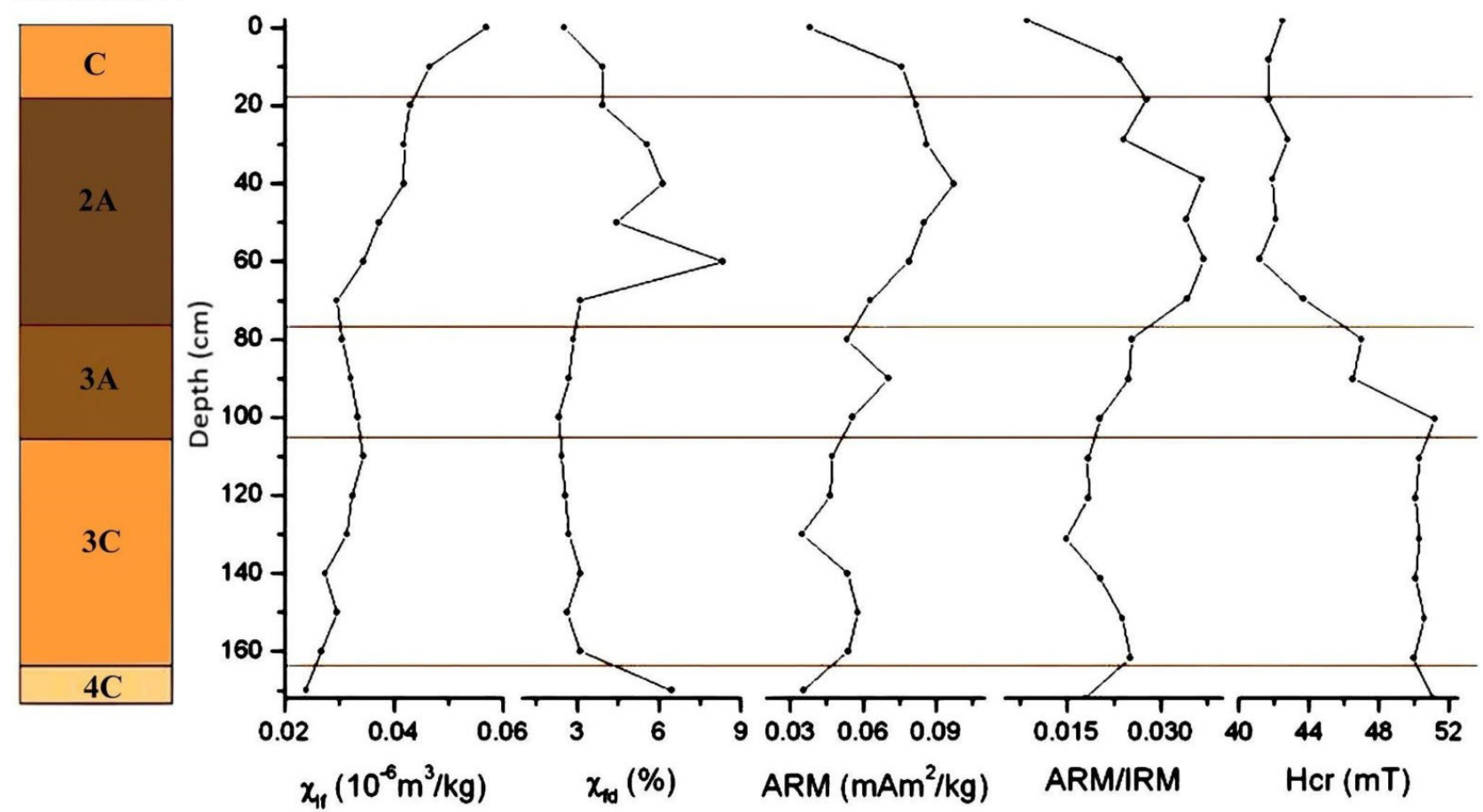

Magnetic properties of Hornos 2 profile.

poorly sorted materials, predominately silty with a mixture of sand grains and inclusions of redeposited soil micro-peds enriched with clay (Figures $10 \mathrm{a}, 10 \mathrm{c}$ and $10 \mathrm{~d})$. It is very likely that the soil was formed from alluvial and colluvial pedosediments eroded from the Sierra Boquillas and the geomorphic unit Q3b. In general, the sand particles are composed of quartz, micas, feldspars and metamorphic rock fragments. The particles have angular and irregular shape and usually show low degree of weathering (Figure 10e and 10f).

The Holocene paleosols contain some carbonates in the matrix and in the pores as micritic hypocoatings (Figures 10a, and 10b), which indicates a very incipient leaching and predominantly intra-horizontal process. Furthermore, humus accumulations are observed in the matrix and in the pores, indicating moderate humification (Figures $11 \mathrm{a}$ and $11 \mathrm{~b})$. Some microareas are enriched with dark organic pigment and show a granular structure and bioturbation (Figure 11d). Redoximorphic features (Fe and Mn mottles) are mainly associated with cracks in the groundmass (Figures 11e and 11f). We also observed heterogeneous coatings consisting of clay, silt, and humus in the pores, interpreted as agrocutans (coatings of clay, humus, and silt in the pores, produced by the disturbance related to farming practice) (Bullock et al., 1985). Also several charcoal flakes of diverse sizes are abundant and mixed with the matrix (Figure 11c).

\section{Discussion}

\subsection{PEDOGENIC PROGESS AND ENVIRONMENTAL FORMATION OF BOP}

In general, BOP shows a gray coloration (see Table 2) associated with the presence of organic matter. The analytic results from the Hornos 2 and Canal 2 profiles present more or less similar soils features, including darker brown-gray color, silty texture, pedogenic structure, subangular blocks, pores, and roots. The 3A horizon from Hornos 2 was dated by $14 \mathrm{C}$ with organic soils at 4090-3880 cal BP, and 


\section{Canal 2}

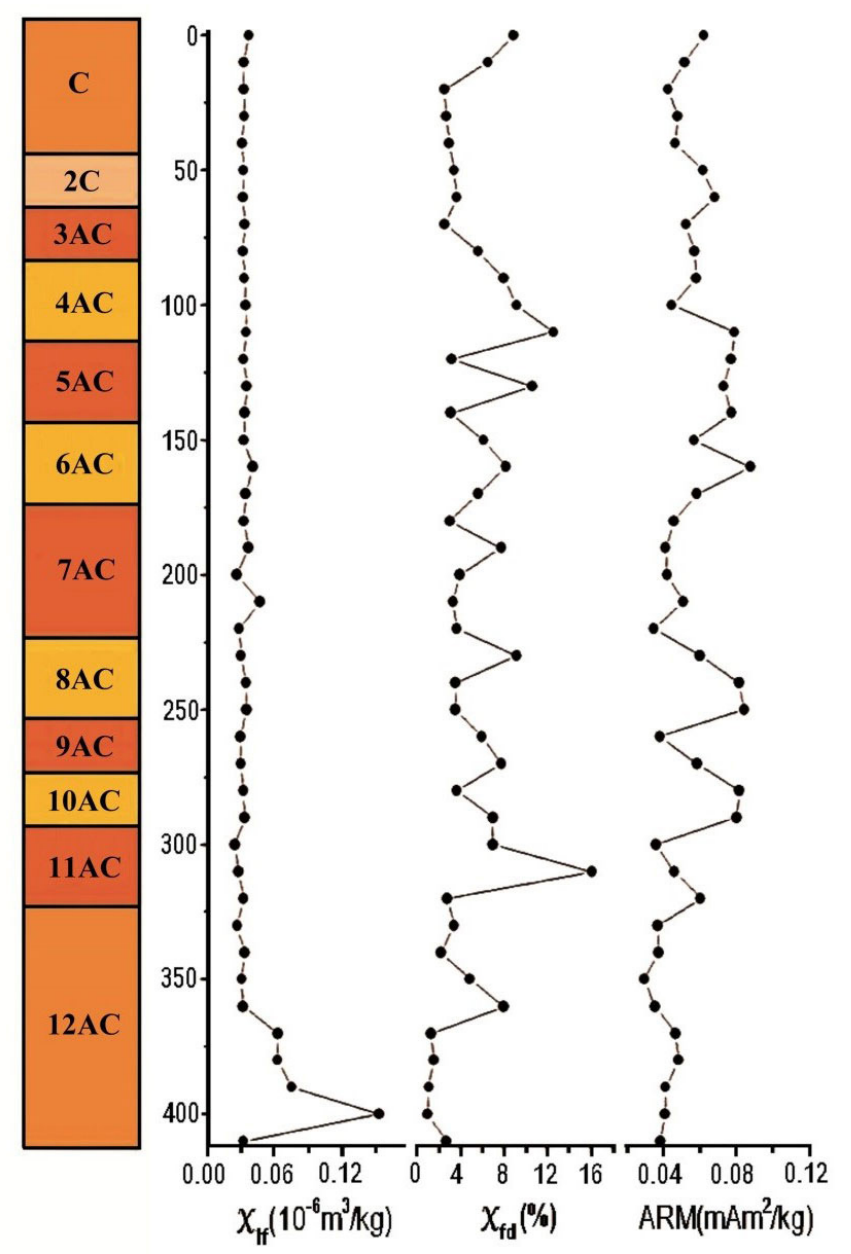

Figure 9 Magnetic properties of Canal 2 profile: $\chi_{\text {If }}$ low frequency magnetic susceptibility, $\chi_{\mathrm{fd}}$ frequency dependent magnetic susceptibility and ARM anhysteretic remanent magnetization.

2C horizon from Canal 2 was dated by $14 \mathrm{C}$ with carbonates at 2368-2475 cal BP (Cruz-y-Cruz et al., 2014). We can conclude that the soil formation in both profiles is the result of the same soil development that took place during the late Holocene at the site area, which constitute a Pedological Unit referred to as the BOP. The development of upper BOP coincides with the period of more extensive occupation at the site; the soil developed on alluvial sediments by incipient pedogenic processes (weathering, humification, aggregation, and carbonation). These paleosols were buried by silty sediments containing charcoal associated with archaeological materials.
The changes in particle sizes appear to be indicative of a polycyclic soil, with periods of pedogenesis interrupted by the incorporation of new materials from the alluvial and colluvial deposits eroded from the uplands. This new material incited a new depositional event, followed by a new pedogenetic event. This multiple pedogenetic cycle is observed on the studied profiles. The abrupt textural changes from one horizon to another show lithological discontinuity, confirming that is a polycyclic soil that has evolved from predominantly silty colluvial-alluvial material eroded from the upper parts of the Sierra de Boquillas that were added at different times, disrupting the pedogenetic process without interrupting it. The constant input of new alluvial deposits did not allow impressive soil development, and the main pedogenic process was the incorporation of organic matter; however, the significant clay content in the soil horizons is an important feature of their pedogenesis.

Based on our analysis, is very likely that the Boquillas soils were developed from alluvial-colluvial materials (soils and sediments) eroded from the Sierra de Boquillas and from the Q3b unit of the flood plain, forming a poorly sorted alluvial fan with low textural maturity, immersed in a fine silt matrix.

At the Hornos 2 profile, the 2A and 3A horizons show the greater pedogenetic process that incorporates organic matter, the formation of incipient soils with undersized sub-angular block structure, and low organic carbon content. The content of Fed shows an increment with respect to the overlying sediment, but the micromorphology analysis shows that the Fed has been provided largely by the soil micro-aggregates. Accumulations of secondary carbonates are also observed in some pores, as well as very few concretions of iron oxides, indicating redox processes.

These soils reveal natural processes indicated by the presence of iron and manganese oxides, and carbonates that could be related to weathering or anthropic activities. Regarding the latter, it is interesting that the maximum content of carbonates was observed in soil horizons associated with 

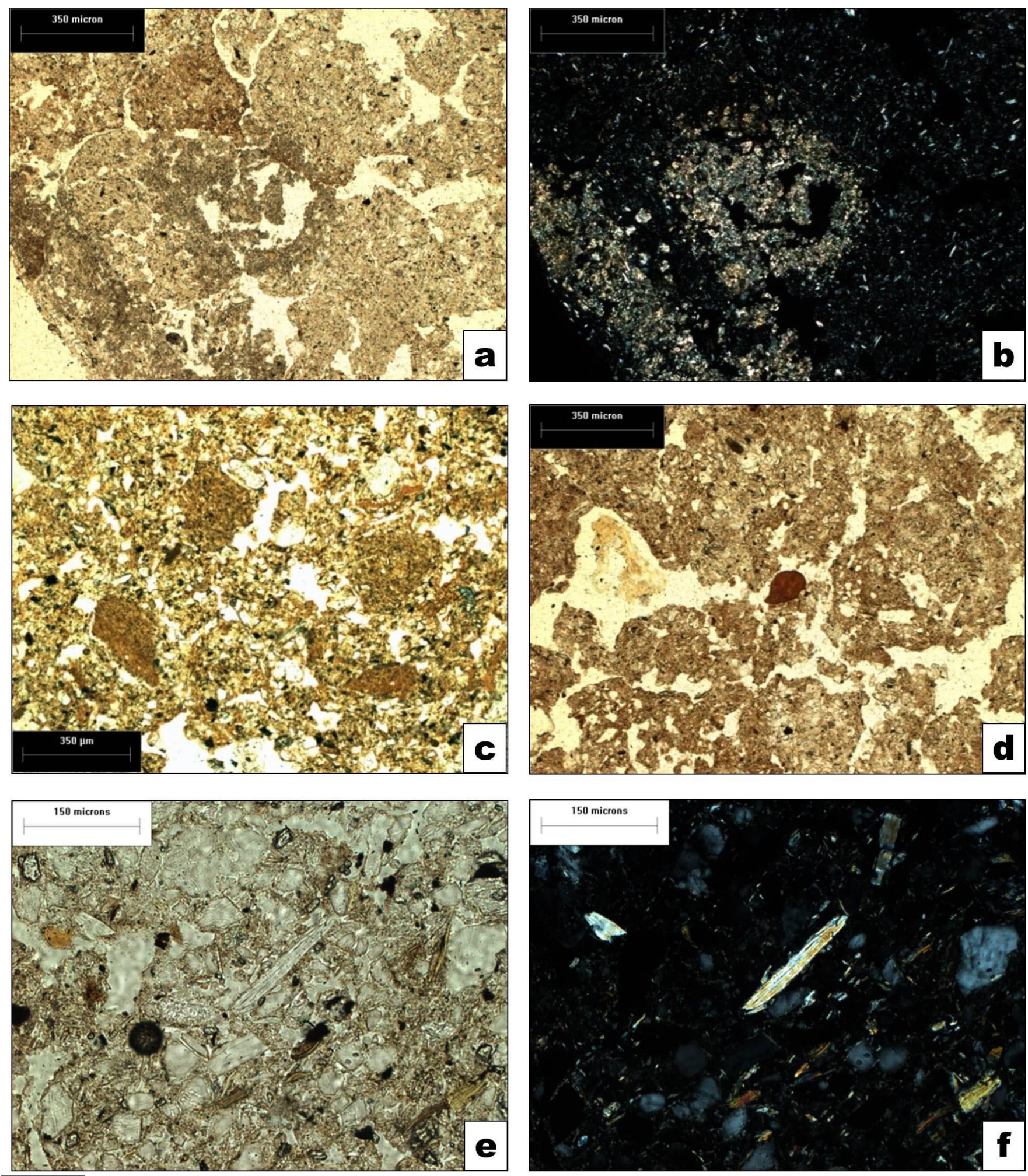

Figure 10 Micromorphological features of BOP: groundmass composition. a) Silty groundmass, incomplete pedality, micritic hypocoating and infilling in the center, PPL; b) Same as a), N+: note strong interference colours of micrite; c) Redeposited soil fragments enriched with clay, PPL; d) Uneven dark humus pigmentation, compact clayey block (probably a coating fragment) in the center, PPL; e) Muscovite particle, PPL; f) Same as e), N+: muscovite still has high interference colours but already demonstrates thin cracks and deformation at the biedges. Photos by T. Cruz-y-Cruz and S. Sedov. 

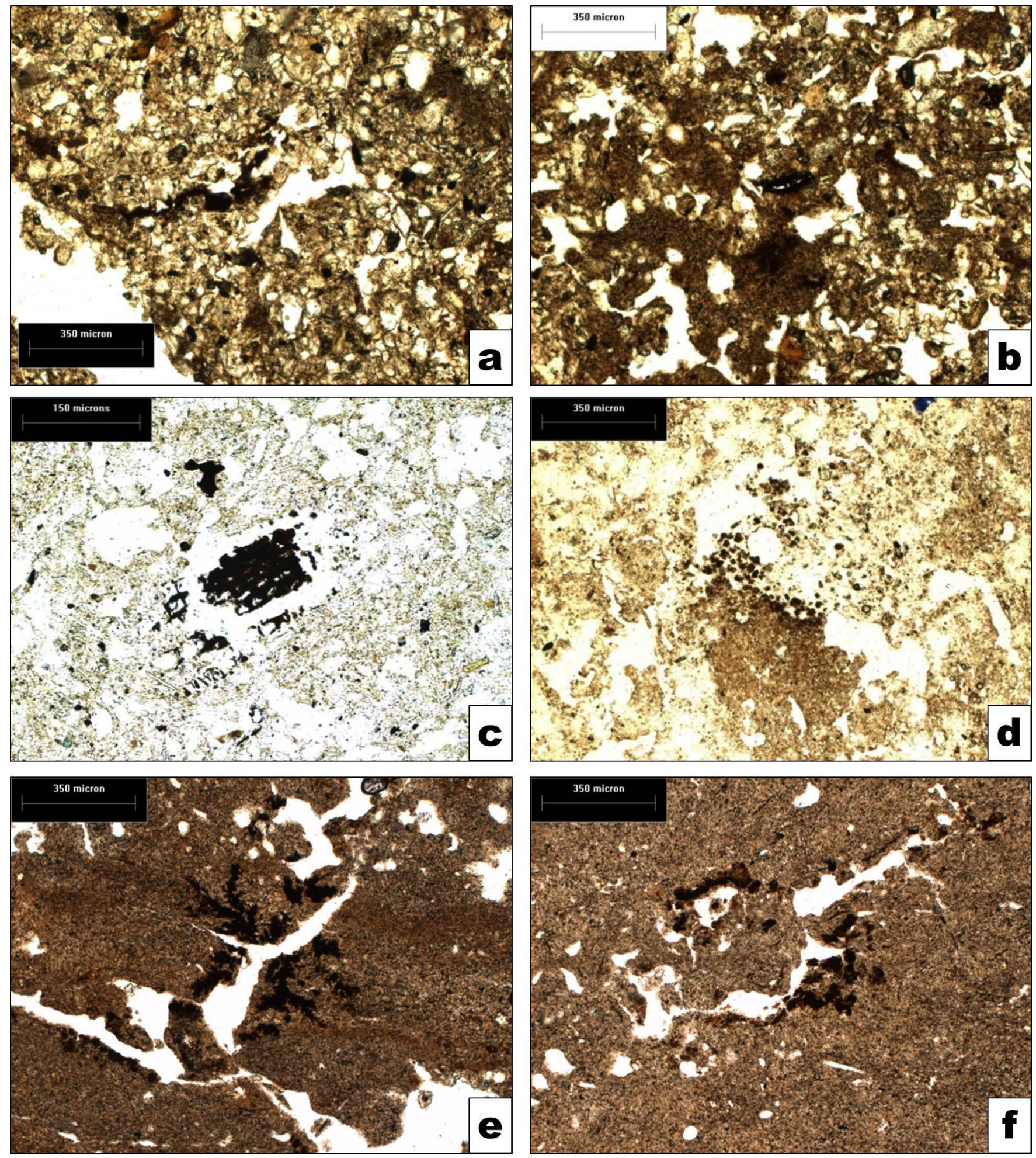

Figure 11 Micromorphological features of BOP: humus, biogenic and redox features. a) Charred organic material near the pore, PPL; b) Areas with strong humus pigmentation, PPL; c) Charcoal incorporated in the groundmass, PPL; d) Impure infilling, PPL; e), f) Fe-Mn mottles and hypocoatings associated with cracks (e) and pores (f). Photos by T. Cruz-y-Cruz and S. Sedov. 
ovens, so that this increase may be related to the formation of carbonate due to burning (Aleksandrovskii, 2007). Also, the presence of bone fragments in the matrix, agro-cutans in the large pores, and fragments of surface crust, suggests that soil development has been disrupted by cultural processes.

At the Canal 2 profile, the characteristics of $3 \mathrm{AC}$, $4 \mathrm{AC}, 5 \mathrm{AC}, 6 \mathrm{BC}, 7 \mathrm{BC}, 8 \mathrm{AC}, 9 \mathrm{AC}, 10 \mathrm{AC}$, and $11 \mathrm{AC}$ horizons are very similar and uniformed, and could be correlated with similar units at the Hornos 2 profile. The depth and development of pedosequence show the succession of short periods of instability, interspersed with relatively long periods of stability that allowed pedogenesis and development of cumulic soil. In all horizons, the predominant pedogenetic process is humification, traces of which are still observed in some pore coatings containing humus and biogenic structure formation. Clays are commonly associated with ion oxides. The percentage of clay in the Boquillas soil is high (2A $13.3 \%$, 3A $6.4 \%$, 6AC $23.7 \%$, 8AC $65.1 \%$, and 10AC $26.7 \%$ ), and was inherited from the parent material, including micro-aggregates of soils originated at the upland Q3b unit that eroded down into the alluvial plain.

In addition, previous studies showed that the predominant clays in soils are smectites, although illites and kaolinites were also identified (Cruz-yCruz et al., 2014). It is interesting to observe the increase in the content of illites in the horizons $\mathrm{A}$ and $\mathrm{AC}$, with respect to that of the $\mathrm{G}$ horizons, which has been interpreted in a preliminary way as a process of illitization of smectites promoted by the semi-arid climate (Retallack, 2001).

In summary, the main pedogenic processes that promoted the development of late Holocene soils are the incipient weathering of minerals, the incorporation of organic matter to the mineral fraction (humification), and the accumulation of calcium carbonates (carbonation). The first two attributes are of short duration of 10-100 years (Targulian and Goryachkin, 2004). During the late Holocene, the alluvial fan dynamics consisted of alternate periods of erosion - with material removal - and stable periods of deposition that allow pedogenesis for short periods of time. These phenomena promoted the formation of cumulic soils with incipient pedogenesis. The profiles analyzed in this paper are in zones of the alluvial fan susceptible to receiving the principal accumulation of colluvial-alluvial material eroded from the upland. We observed a positive pedogenic process, in which foreign material was added to the preexisting soil and evolve in new soil formation.

The Boquillas paleosol attributes indicate that soils were developed in an environment of low stability, dominated by erosion-sedimentation processes, which promoted the formation of cumulic soils sequences with incipient development. These processes occur principally in semiarid climates, which is corroborated by the pedogenic processes identified in the soil (weathering and incipient humification and carbonation), indicating low water availability. Also, the isotopic composition of organic matter indicates a vegetation cover of mixed composition, probably of desert scrub, leguminous trees, and some grassland (Carpenter et al., 2015; Cruz-y-Cruz et al., 2016). Also, the delimitation of the geomorphological units of the alluvial fans allowed identifying that the BOP was formed in the Q4a unit, which was formed during the late Holocene in a dry climate, according to Bull's model (1991).

\subsection{ANTHROPIC IMPACT ON BOP}

The anthropic impact on the Holocene soils at La Playa site could be observed from different studies. The study of the magnetic properties shows that enrichment of magnetic minerals was observed in some horizons. This is remarkable because it is related to anthropogenic sediments, and the magnetic minerals are more prominent in the profiles near the Hornos Alineados Loci, an area with many roasting pits. Magnetic susceptibility $\chi$ has a maximum in the silty sediments at the surface ( $\mathrm{C}$ horizon), but this maximum does not coincide with an enhancement of other indicators of pedogenesis. It has been observed in some studies 
(LeBorgne, 1960; Kletetschka and Banerjee, 1995) that fire produces an enhancement of magnetic susceptibility in soils and increases the concentration of fine and ultra-fine grains of low coercivity magnetic particles. Magnetic enhancement due to pedogenesis has similar properties, but we must consider that BOP has very low development of pedo-features, therefore the pedogenetic processes cannot be the principal source for the high values of magnetic parameters; hence, a more likely explanation is given by human activities. Magnetic properties indicate that magnetic particles in BOP probably were produced by the heat of ovens and funeral pyres made by the human occupants of the floodplain. The micromorphological analysis allowed us to observe that in all the horizons the features showing weathering, humus pigmentation, carbonate accumulation, leaching, and incipient redox processes are very similar. The micromorphological features suggests that the soil was modified probably because the sediments were removed and altered by humans. The La Playa site was inhabited at least for a millennia and storage pits, pit-houses, roasting pits, graves for the death, canals, berms, and corn fields for cultivation are archaeological features that heavily modified the Boquillas floodplain.

Despite the poor development of the Boquillas Paleosol, it was the setting of the most important human occupation of the site during the EAP. In this period, human occupation was intensive, as evidenced by the large number of burials and hearth ovens of various types and sizes (between 3000 and 4000), which continuously are being exposed by erosion. Added to this, the extensive occupation and complexity of the agricultural system at the site is an indication that the soils could sustain intensive farming for long periods of time. Also, the BOP unit presents loamy textures, with an important amount of clays: $23.7 \%$ in stratum $4 \mathrm{BC}, 36.1 \%$ in $6 \mathrm{AC}$ and $26.7 \%$ in $8 \mathrm{AC}$ (Canal 2) and $13.3 \%$ in $2 \mathrm{~A}$ (Hornos 2). These textures provide good aeration, adequate retention of water and nutrients and good root penetrability, these being excellent attributes for the crop. The clay mineralogy shows a predominance of smectite, which favors the cation exchange capacity, and therefore the availability of nutrients, which makes the soils suitable for agriculture despite the lower organic matter content. The main limiting factor for cultivation would be the low water availability due to semiarid climatic conditions. However, this was resolved by the people of La Playa by implementing an agricultural system with irrigation channels. This system has also been observed at the Las Capas archaeological site in Tucson, whose occupation occurred during the EAP (Herr, 2009; Vint, 2018), which indicates that it was probably a system widely spread and used by the early farmers in the southwest U.S. and northwest Mexico. Successful farming in semiarid climates has antecedents since the Neolithic in the dry regions of Asia (Israel, Jordania, Yemen), Africa, and North and South America (U.S., Mexico, Peru, Chile), through the implementation of rainwater harvesting systems (Bruins et al., 1986).

\section{Conclusions}

The BOP pedocomplex, which was established during late Holocene times, is poorly developed and strongly affected by the instability of the landscape affected by natural and human influences. Previous analyses show that the BOP was developed over several pedogenic short-lasting cycles, with weathering, humification and carbonation as the most important processes of pedogenesis. This soil was the ground cover when the site experienced its maximum population during the EAP. The agricultural activities (e.g., corn fields, berms, irrigation canals), and the daily living activities identified from the archaeological evidence (e.g., digging graves for human and dogs, cremations, roasting pits, pit-houses, storages pits) greatly impacted soils and promoted accelerated degradation. Many of the human-induced soil transformation processes and properties are more typically associated with urban environments than with agricultural societies. 
The BOP are incipient soils that in other conditions would not be good for agriculture. However, the unique situation at the La Playa site with reworked Pleistocene soil material, with an important component of smectite clays, and with the agricultural field system of fields watered with long networks of irrigation canals from the Boquillas river, constitute an excellent matrix for the agricultural activities that were developed at the site. These practices probably promoted significant changes in soil properties that were identified by the micromorphological analysis, although more detailed studies are needed to assess its extent and intensity. We believe that these kinds of interdisciplinary studies are an important tool to study the anthropogenic impact on ancient and modern soils and consider the social dimensions and impacts in the cultural landscapes.

\section{Acknowledgements}

This research was funded by the Project PAPIIT N106616 and CONAGYT 236623. We acknowledge the support of the Programa de Becas Posdoctorales en la UNAM, Instituto de Investigaciones Antropológica, UNAM; Instituto de Geología, UNAM; Estación Regional del Noroeste, IGL, UNAM; AARF-Argonaut Archaeological Research Fund, University of Arizona; National Geographic Society; Archaeological Project La Playa of INAH-Sonora; Elisa Villalpando and Vance T. Holliday.

\section{References}

Aleksandrovskii, A.L., 2007, Pyrogenic origin of carbonates: Evidence from pedoarchaeological investigations: Eurasian Soil Science, 40(5), 471-477. https://doi. org/10.1134/S1064229307050018

Balter, M., 2013, Archaeologists Say the 'Anthropocene' Is Here-But It Began Long Ago: Science, 340(6130), 261-262.
Braidwood, R.J., 1960, The agricultural Revolution: Scientific American, 203, 130-148.

Bruins, H.J., Evenari, M., Nessler, U., 1986, Rainwater-harvesting agriculture for food production in arid zones: the challenge of the African famine: Applied Geography, 6, $13-32$.

Bull, W.B., 1991, Geomorphic Responses to Climatic Change: Oxford University Press, Oxford, $326 \mathrm{p}$.

Bullock, P., Federoff, N., Jongerius, A., Stoops, G., Tursina, T., Babel., U., 1985, Handbook for Soil Thin Section Description: Waine Research Publications. Wolverhampton, UK., 152 p.

Carpenter, J., Sánchez, G., Villalpando, E., 2003, Sonora Precerámica: Del Arcaico y del Surgimiento de Aldeas Agrícolas: Arqueología, 29, 5-29.

Carpenter,J., Sánchez, G., Villalpando, E., 2005, The Late Archaic/Early Agricultural Period in Sonora, Mexico, in Vierra, B. (ed.), New Perspectives on the Late Archaic Across the Across the Borderlands, University of Texas Press, Austin, 3-40.

Carpenter, J., Villalpando, E., Sánchez, G., 2008, Prehispanic Environmental and Cultural Dynamics on the Southern Periphery, in: Altschul, J., Rankin, A. (eds.), Fragile Patterns: Perspectives on Western Papaguería Archaeology, SRI Press, Tucson, Arizona, 287-308.

Carpenter, J.P., Villalpando, E., Sánchez, G., 2009, La Playa: An Early Agricultural period landscape: Archaeology Southwest, 23(1), 14.

Carpenter,J., Sanchez, G., Watson,J., Villalpando, E., 2015, The La Playa Archaeological Project: Binational interdisciplinary research on long-term human adaptation in the Sonoran Desert: Journal of the Southwest Special Issue: Seeds in the Sand: Emerging Approach for Understanding the Sonoran Desert, 57, 2 and 3, 213-264. 
Copeland, A., Quade, J., Watson, J.T., Mclaurin, B.T., Villalpando, E., 2012, Stratigraphy and geochronology of La Playa archaeological site, Sonora, Mexico: Journal of Archaeological Science, 39, 2934-2944.

Cruz-y-Cruz, T., Sedov, S., Sánchez, G., Pi-Puig, T., Pustovoytov, K., Barceinas-Cruz, H., Ortega-Guerrero, B., Solleiro-Rebolledo, E., 2014, Late Pleistocene-Holocene palaeosols in the north of Sonora, Mexico: chronostratigraphy, pedogenesis and implications for environmental history: European Journal of Soil Science, 65, 455-469.

Cruz-y-Cruz, T,. Sánchez, G., Sedov, S., TerrazasMata, A., Solleiro-Rebolledo, E., TovarLiceaga, R.E., Carpenter, J., 2015, Spatial variability of late Pleistocene-early Holocene soil formation and its relation to early human paleoecology in Northwest Mexico: Quaternary International, 365, 135-149.

Cruz-y-Cruz, T., Pérez-Crespo, V.A., Pustovoytov, K., Sedov, S., Morales-Puente, P., TovarLiceaga, R.E., Arroyo-Cabrales, J., TerrazasMata, A., Sánchez-Miranda, G., 2016, Paleosol (organic matter and pedogenic carbonates) and paleontological $\quad \delta^{13} \mathrm{C}$ records applied to the paleoecology of Late Pleistocene-Holocene in Mexico: Quaternary International, 418, 147-164.

Dearing, J.A., Hay, K.L., Baban, S.M.J., Huddleston, A.S., Wellington, E.M.H., Loveland, P.J., 1996, Magnetic susceptibility of soil: An evalation of conflicting theories usung a national data set: Geophysical Journal International, 127, 728-738.

Diehl, M.W., 2009, Early Agricultural period food provisioning and foraging: Archaeology Southwest, 23(1), 12.

Herr, S., 2009, The latest research on the earliest farmers: Archaeology Southwest, 23(1), 1-3.

Huckell, B.B., 1995, Of marshes and maize: Preceramic agricultural settlements in the Cienega Valley, southeastern Arizona:
Anthropological Papers of the University of Arizona Number 59. Tucson, AZ: The University of Arizona Press.

King, J.W., Banerjee, S.K., Marvin, J.A., Özdemir, Ö., 1982, A comparison of different magnetic methods for determining the relative grain size of magnetite in natural matrials: some results from lake sediments: Earth and Planetary Science Letters, 59, 404-419.

Kletetschka, G., Banerjee, S.K., 1995, Magnetic stratigraphy of chinese loess as a record of natural fires: Geophysical Research Letters, 22, 1341-1343.

LeBorgne, E., 1960, Influence du feu sur les propriétés magnétiques du sol et sur celles du schiste et du granite: Annales de Géophysique, 16, 159-195.

Mabry, J.B., 2008, Las Capas: Early irrigation and sedentism in a southwestern floodplain: Anthropological Papers No. 28. Tucson, AZ: Center for Desert Archaeology, 457 p.

Mabry, J.B., Swartz, D.L., Wocherl, H., Clark, J.J., Archer, G.H., Lindeman, M.W., 2002, Archaeological investigations of early village sites in the Middle Santa Cruz Valley. Anthropological Papers No. 18. Tucson, AZ: Center for Desert Archaeology.

Martínez-Lira, P., Arroyo-Cabrales, J., Carpenter, J., 2011, Faunal Remains and Subsistence Practices at the Archaeological Site La Playa (SON:F:10:3) in Sonora, Mexico: Kiva, 77(1), 33-58.

Martinez-Tagueña, N., Sanchez, G., 2005, Of roasting pits and plant remains: the paleoethnobotanical research program at the La Playa site, Sonora Paper presented at the Symposium Paleoetnobotanical Research in Mexico. Society for Economic Botany, Forthworth, Texas, 6-11.

McAuliffe, J.R., Van Devender, T., 1998, A 22,000year record of vegetation change in the northcentral Sonoran Desert: Palaeogeography, Palaeoclimatology, Palaeoecology, 141, 253-275. 
McAuliffe, J.R., Sundt, P.C., Valiente-Banuet, A., Casas, A., Viveros, J.L., 2001, Pre-columbian soil erosion, persistent ecological changes, and collapse of a subsistence agricultural economy in the semi-arid Tehuacán Valley, Mexico's 'Cradle of Maize': Journal of Arid Environments, 47, 47-75.

McClung, E., Solleiro-Rebolledo, E., GamaCastro, J., Villalpando, J.L., Sedov, S., 2003, Paleosols in the Teotihuacan valley, Mexico: evidence for paleoenvironment and human impact: Revista Mexicana de Ciencias Geológicas, 20(3), 270-282.

McLaurin, B., Kula, J., Aaron, H., 2007, "Resumen de las Actividades Geológicas La Playa, Sonora, México. Diciembre 2005Mayo 2006", in Villalpando, E., Carpenter, J., Watson, J. (eds.), Proyecto Arqueológico La Playa, VIII Informe, Temporadas 2005 y 2006.

Mehra, O.P., Jackson, M.L., 1960, Iron oxide removal from soils and clays by a dithonitecitrete system buffered with sodium bicarbonate: Clays and Clay Minerals, 7, 317-327.

Pérez, R.G., 1985, Geografía de Sonora, in Hopkins, A. (ed.), Historia General de Sonora I. Periodo Prehistórico y Prehispánico, Gobierno del Estado de Sonora, 111-172.

Price, D., Brown, J.A., 1988, Prehistoric Hunter Gatherers: The Emergence of Cultural Complexity, Academic Press, 472 p.

Retallack, J.G., 2001, Soils of the Past. An introduction of paleopedology: Blackwell Science, $520 \mathrm{p}$.

Sánchez, G., 2016, Los Primeros Mexicanos. Late Pleistocene and Early Holocene People of Sonora. Anthropological papers of the University of Arizona, 76.

Sánchez-Pérez, S., Solleiro-Rebolledo, E., Sedov, S., McClung de Tapia, E., Golyeva, A., Prado, B., Ibarra-Morales, E., 2013, The Black San Pablo Paleosol of the Teotihuacan Valley, Mexico: Pedogenesis, Fertility, and
Use in Ancient Agricultural and Urban Systems: Geoarchaeology: An International Journal 28, 249-267.

Schlichting, E., Blume, H.P., 1966, Bodenkundliches Praktikum: Verlag Paul Parey, Hamburg.

Stoops, M., Marcelino, V., Mees, F., 2010, Interpretation of micromorphological features of soils and regoliths. Elsevier. Amsterdam \& Oxford. 720 p.

Targulian, V.O., Goryachkin, S.V., 2004, Soil memory: Types of record, carriers, hierarchy and diversity: Revista Mexicana de Ciencias Geológicas, 21(1), 1-8.

USDA, 2004, Soil Survey Laboratory Methods Manual. Soil Survey Investigations Report 42 Version 4. National Resources Conservation Services, Natural Soil Survey Center, Lincoln, NE.

Van Devender, T.R., 1990, Late Quaternary vegetation and climate of the Sonoran Desert, United States and Mexico, in Betancourt, J.L., Van Devender, T.R., Martin, P.S. (eds.), Packrat Middens: the Last 40,000 Years of Biotic Change. University of Arizona Press, Tucson, 134-165.

Vidal, R., 2005, Las regiones climáticas de México: Instituto de Geografia, UNAM, México City, $212 \mathrm{p}$.

Villalpando, E., Carpenter, J., Watson, J., 2007, Proyecto Arqueológico La Playa, VIII Informe, Temporadas 2005 y 2006, Archivo Técnico del INAH.

Vint, J.M., 2018, The Southwest Archaic in the Tucson Basin, in Vierra, B. (ed.), The Archaic Southwest: foragers in an arid land, University of Utah Press, Southlake, Utah, 66-97.

Watson, J., 2011, Bioarchaeology of the First Farmers in the Sonoran Desert. http://www.archaeologysouthwest.org/ pdf/pecos2008_watson.pdf $>$, accessed November, 2015. Archaeology Southwest, Tucson. 
Whitney, G.J., Sinensky, R.L., Tinseth, G.L., Steinbrecher, B.P., South, J.M., 2014, Las Capas Archaeological Project: Field Methods, the Retention Basin, and Extramural Feature Descriptions, Technical Report No. 2014-01, Desert Archaeology, Inc., Tucson, 97 p.

World reference base for soil resources, 2006, A framework for international classification, correlation and communication. Rome: Food and Agriculture Organization of the United Nations.

Worm, H.U., 1998, On the superparamagneticstable single domain transition for magnetite, and frequency dependence of susceptibility: Geophysical Journal International, 133, 201-206. 